\title{
An Anthropological Perspective on the Climate Change and Violence Relationship
}

\section{Jen Shaffer}

0110 Woods Hall

4302 Chapel Lane

Department of Anthropology

University of Maryland

College Park, MD 20742

lshaffe1@umd.edu

301.405.1441

ORCID: orcid.org/0000-0002-0635-0576

The final publication is available at Springer via http://dx.doi.org/10.1007/s40641-017-0076-8

\begin{abstract}
Purpose of Review: This review explores the complex climate change-violence relationship through an anthropological lens, focusing on the interacting social and environmental conditions that constrain individual choices for violence. Evidence and methods used by anthropologists to identify violent events, as well as anthropological theories regarding why individuals choose violence, are discussed. A general social-environmental model is presented and explored through four case studies, two archaeological and two ethnographic.

Recent Findings: Recent research with historic and contemporary case studies suggests that resource uncertainty interacts with a complex array of pre-existing social and environmental conditions, including environmental degradation, poor governance, and social inequality, to promote violent responses both before and following climatic changes. Individuals may choose to avoid violence where supporting, cooperative mechanisms exist.

Summary: Given that individuals make choices to respond violently or not based on their perceptions of these complex, interacting social and environmental conditions, violence in response to global climate change is not inevitable.
\end{abstract}

\section{KEYWORDS}

cooperation; governance; resource uncertainty; social-environmental system; social inequality; structural violence

\section{ACKNOWLEDGEMENTS}

Thank you to Drs. Elisabeth Gilmore and Brian Sodden for their invitation to contribute to this special edition of Current Climate Change Reports. There is no conflict of interest. 


\section{INTRODUCTION}

In April 2017, people around the world gathered non-violently in protest of changes to US government policy that would negatively impact science and global climate change mitigation and adaptation efforts. In Washington, DC, rally speakers and protest signs at the March for Science and the Peoples' Climate March talked about the link between climate change and violence. The speakers and signs warned of projected climate events and trends as a 'threat multiplier' affecting human security via impacts to infrastructure, food and water security, the spread of disease, migration of humans and other species, and government stability. The IPCC's Fifth Assessment discusses this threat multiplier effect, and a recent US Department of Defense report describes "climate change as an urgent and growing threat to our national security" (p.3) $[1,2]$. Both documents recognize the underlying issues that climate change will exacerbate, including poverty, social tensions, environmental degradation, and poor governance, and which could lead to outbreaks of violence through a complex causal chain. Yet in public discourse the fact that climate change will lead directly to violence, particularly amongst the poor, is taken as seemingly inevitable without much thought to the complex pathways it could take or that people can choose to cooperate in response to climate stress without resorting to violence.

But is violence under projected global climate changes really inevitable? Concerns regarding the potential for increased violence and mortality under climate change projections are legitimate and justifiable. A growing number of studies have found correlations between lethal violence and climate change, including interpersonal conflict and war [3-5]. Closer investigation regarding the context of this relationship usually reveals a complexity of interacting prior conditions influencing the documented outbreaks of violence and lethal aggression following climate shocks and under changing conditions. Structural violence may also heighten violence and mortality risks for various population segments under climate change due to poor governance, health, and economic policies. Structural violence is defined here as institutional structures, policies, and ideologies valuing some segments of the population more than others, and that prevent less-valued people from meeting their basic needs [6-8]. Ethnographers, archaeologists, and others have also documented cases where communities cooperated, or at least not resorted to violence, to respond to severe weather events and climate shifts in temperature and precipitation [8-11]. Therefore, from an anthropological perspective, establishing the conditions that promote lethal violence under changing climate conditions is important for the development of successful, non-violent responses and adaptation to future climate uncertainty.

The purpose of this review is to assess the relationship between climate change and violence from an anthropological perspective. Here, I focus on interpersonal and collective, physical violence in response to climate events and changes that result in mortality, including one-on-one aggression, violent conflict, and war. However, the review also considers less lethal forms of physical violence where relevant, and recognizes that structural violence may influence 
physically violent responses as well as result in differential mortality rates. I begin with an overview of anthropological evidence for physical violence and how researchers in this discipline theorize both participation in violence and the climate change-violence relationship. An exploration of archaeological and contemporary case studies highlighting the complex interplay of conditions that influence violent responses to triggering climate changes and events follows. I finish with a discussion of research needs and the role for anthropology in answering these important questions.

\section{Taking an Anthropological Perspective}

Following decades of research studying the role of climate in shaping culture, human behavior, and hominin evolution, the American Anthropological Association (AAA) issued a statement in 2015 on humanity and climate change [12]. This statement drew on work by the AAA Global Climate Change Task Force, formed in 2010, synthesizing a range of archaeological and ethnographic studies focused on human responses and adaptation to climate change around the world [8]. The AAA statement acknowledges global climate change as a human problem that intensifies underlying social problems, accelerates migration, destabilizes communities and nations, and worsens the spread of disease. However, it does not expressly predict violence and war as an outcome of climate change; citing the archaeological record as evidence that diversity and flexibility increase resilience to climate stressors. More recently, after President Donald Trump announced his rejection of the 2015 Paris Accord, the AAA issued a brief note confirming their commitment to improving our understanding of how climate change is affecting humanity, how people are responding, and finding solutions to climate change problems [13]. The authors of this more recent statement highlight the magnitude of the threats that climate change poses, writing that they affect "our global stability as well as our collective sense of cultural identity, our well-being, and our national security."

These official statements by the AAA reinforce other messages regarding the complexity of climate change interactions with human societies, behaviors, and well-being. But what can anthropology bring to the discussion of climate change and violence that other disciplines cannot? Anthropology's holistic study of culture and humanity in all its diversity through space and time, offers a unique perspective to understand the context of when, why, and how people might respond to climate change with violence. This literature review draws heavily on research in archaeology, socio-cultural anthropology, and biological anthropology, three of the four subdisciplinary fields traditionally ascribed to anthropology.

\section{Anthropological Evidence and Interpretation}

Anthropologists must first establish the occurrence of physical violence before seeking social and environmental causal explanations. They use diverse interpretive methods to analyze data 
that includes human biological, observational, oral, documentary, material, and environmental evidence (Table 1). The most direct form of evidence for physical violence comes from the human body itself, where a projectile or blade lodged in the skeletal remains or soft tissue is incontrovertible proof that a life ended violently [14-16]. Examination of fossils, skeletal remains, and preserved soft tissues lacking this obvious evidence may show peri- and postmortem trauma that can be ascribed to violence but this requires informed interpretation. Controversy will remain in some cases of dismemberment or cannibalism where mortuary customs may confuse issues of violence with respect for the dead [17]. Additionally, not all forms of physical violence leave marks on the skeleton, soft tissue is frequently lacking in historic and prehistoric remains, and discovery depends upon good preservation conditions, excavation support, and being found. Documentary evidence, behavioral observations, and oral accounts, particularly with contemporary peoples, can provide direct evidence although the memory and positionality of participants and observers may introduce bias [18].

Where direct evidence is lacking, anthropologists make inferences based on the patterns they observe in available data. Artefacts like weapons, defensive features in architecture, and relocation of settlements to more defensible positions indicate potentially elevated risks for physical violence [17, 19-22]. Laws, policies, and ideologies inscribed on architectural features or recorded in texts may indicate societal shifts and institutional support for social inequalities. Analyzed bureaucratic records including agricultural yields, irrigation system use and maintenance, market prices, imports and exports, taxes, census data, and military supplies and movements can offer insights into the daily stresses experienced by people living in a particular city or state through their resource consumption [22, 23]. Excavated food remains document dietary differences associated with social and economic class or shifts linked to overharvest, rationing, or famine at the household level. Healed injuries, non-specific skeletal stress, and stunting could point to social inequalities and/or periods of crises and social upheaval, and therefore an increased probability of violence $[15,16,24]$. People may not directly discuss experiences of daily stress and violence but their interview responses, oral histories, observed behaviors, and livelihood adaptations may speak to physically violent episodes in their lives or that of previous generations [10].

It is important to note that in interpreting direct and indirect evidence, the potential for researcher bias and misinterpretation exists. In particular, deeply ingrained Western cultural beliefs about the darker side of human nature can distort interpretations [25]. Active awareness of biases and beliefs, both personal and disciplinary, while conducting research and assessing published findings encourages greater scientific objectivity. New discoveries and information, as well as ongoing, discussions between researchers also promote improved understandings. Experience and expertise, combined with triangulating multiple lines of evidence, strengthen the ability of anthropological researchers to rigorously interpret observed phenomena and context. Practitioners often borrow relevant methods and data from other anthropological fields and 
scientific disciplines. Increasingly anthropologists are members of inter-, multi-, and transdisciplinary teams where each member contributes their expertise towards answering a complex question. Research projects seeking to understand the multifaceted impacts of climate change on social-environmental systems and develop appropriate, non-violent responses and adaptations epitomize these kinds of studies.

\begin{tabular}{|c|c|}
\hline Evidence Type & Examples \\
\hline Environmental & $\begin{array}{l}\text { landscape features (agricultural fields \& terraces, defensible } \\
\text { locations, etc.); transportation routes; settlement locations \& extent; } \\
\text { water bodies; locations of preferred wild resources; soils; plant \& } \\
\text { animal remains; species ranges; pollen \& charcoal in sediment cores; } \\
\text { middens (food waste); climate (tree rings, corals, stalagmites, } \\
\text { sediment \& ice cores, historic records, etc.) }\end{array}$ \\
\hline Material & $\begin{array}{l}\text { tools; weapons; clothing; cookware \& tableware; storage \& transport } \\
\text { items; architecture; art \& religious objects; raw materials \& } \\
\text { unfinished goods }\end{array}$ \\
\hline Documentary & $\begin{array}{l}\text { inscriptions (monuments, stelae, tombs, buildings, etc.); maps; news } \\
\text { articles \& stories; photographs; video; cadastral records; wills; diaries } \\
\text { \& journals; legal records (laws, policies, regulations, etc.); } \\
\text { agricultural yields \& market pricing; health records; census data; } \\
\text { government agency reports; palace records; religious texts \& } \\
\text { intuitional documents; art \& music; books \& texts; health records; } \\
\text { death certificates; eyewitness accounts; bureaucratic records (lists of } \\
\text { people, commodities, stored goods, etc.); rock art; fieldnotes }\end{array}$ \\
\hline Oral & interviews; oral histories; folktales \\
\hline Observational & participant observation; behavioral observation \\
\hline Human Biological & $\begin{array}{l}\text { fossil \& skeletal remains (healed injures, perimortem trauma, } \\
\text { postmortem trauma); non-specific skeletal stress from famine or } \\
\text { disease (Harris lines, enamel hypoplasia, hair, porotic hyperostosis); } \\
\text { preserved soft tissues; stunting; trauma \& healed injuries }\end{array}$ \\
\hline
\end{tabular}

Table 1. Types of evidence used by anthropologists studying relationships between climate change and violence with exemplars. This list is not exhaustive.

\section{Theorizing Climate-Influenced Violence in Anthropology}

Violence is a complex, cross-cultural phenomenon whose definition is culturally-influenced and evolves through time as social values change. Research correlating lethal physical violence to temperature and precipitation changes, particularly violent conflict, war, and civilization collapse, has grown over the past decade [1,3-5]. However, datasets used for these quantitative 
studies and meta-analyses may only review large-scale conflict events, and can sidestep deeper investigation and comparison of the interacting social and environmental conditions shaping violent responses to climate change [26, 27]. Anthropology's holistic approach has the potential to avoid these pitfalls. This section reviews various explanatory theories for why humans turn to physical violence, cautions against overly environmental deterministic explanations, explores how structural violence affects the climate change-conflict relationship, and discusses the importance of understanding cooperative responses to climate change.

\section{On the Origins of Violence}

Polarized debate surrounds questions regarding the innate capacity of humans for violence, potentially biasing datasets used and interpretation of results [14, 28]. Yet given the ubiquity of violence, and for the purposes of understanding its relationship to climate change, it remains important to understand the conditions which shape violent responses. For approximately $99 \%$ of its evolutionary history, the genus Homo has lived in hunter-forager groups. As such, studies of hunter-foragers offer a window into these supporting conditions at interpersonal and intergroup aggression levels which may not be captured in larger datasets [25]. A recent study tested the relative importance of resource scarcity and individual cost/benefit perceptions by looking at spatial variation for trauma found in prehistoric hunter-forager groups living in central California [29]. Results showed a significant correlation between sharp force trauma and resource scarcity, although no relationship existed between blunt force trauma and environmental productivity or sociopolitical complexity. This suggests that when resources are uncertain, individuals may perceive the potential benefits of lethal violence to outweigh any costs, and that violence levels may vary with resource distribution - affecting mobility and territory size. Some argue, however, that historic and contemporary hunter-foragers face fundamentally different conditions from prehistoric hunter-foragers due to the effects of colonization and globalization [14]. Comparative investigation of lethal violence in 21 mobile hunter-forager groups, both historic and contemporary, found that slightly more than half of the recorded incidents were committed by individuals acting alone, $85 \%$ of victims belonged to the same tribal group as their killer, and that very few of the disputes were over shared resources [30]. Outside factors may have confounded the resource component; however, this work also highlights the importance of individual decision-making regarding violence.

Prehistoric evidence for intergroup violence is rare. Recent recovery of the remains of 12 individuals at Nataruk, Kenya provides unique evidence for a lethal, intergroup conflict event that took place on a productive lakeshore approximately 10,000 years ago [31]. Body positioning, skeletal evidence for sharp and blunt force trauma, and projectiles embedded in body cavities of the men and women show that ten members of the group died violently. Three individuals, including the remaining two who showed no skeletal trauma, may have had their hands bound. The researchers suggest that the violence could either be the result of a raid for 
resources given the location's productivity or an antagonistic response between two different social groups. Human evolutionary theorists working with both paleo and ethnographic evidence of hunter-foragers have proposed that increasing dependence on dense, predictable resources, like those found in wetlands and along lakeshores and coastlines, may have led to increasing intergroup territoriality and conflict [32]. Dense, predictable resources benefit people through year-long access to nutrient rich foods that improve health, reduce child mortality, and support population growth. The paleoanthropological record shows a shift to intensive use of dense and predictable resources in Africa roughly 110,000 years ago, yet evidence for conflict in Africa, and more widely in Europe and Asia, remains thin until the late Pleistocene and early Holocene approximately 10,000 years ago [17, 31-33]. This theory of economic defendability also links to theories on the development of human hypersociality, conflict, and cooperation. Cooperative behaviors unify a group to defend or access vital resources, although there may be a high cost to individuals if these actions require physical violence [32, 34].

Sedentism and domestication enabled profound structural changes in previously small scale societies, such as hunter-forager groups, that promoted larger scale conflict and war [14, 17, 35]. Increasing political, economic, and social organization supported the growth of complex societies with social hierarchies, property ownership, and large scale food production, storage, and hydraulic systems. Formal military institutions and standing armies developed to protect growing populations dependent on these systems around 8000 years ago $[35,36]$. At this level, social organization provided an effective platform to coerce large numbers of individuals to cooperate and participate in war defending home territories, or aggressively seek new resources in other communities, sometimes against their own personal interests [35, 37].

\section{Environmental Determinism in Explaining the Climate Change-Violence Relationship}

Many of the arguments put forth to explain the climate change-violence relationship rely on an environmentally deterministic approach privileging environmental degradation and resource access over other equally, or more, important conditions [7, 38, 39]. Historically, this approach characterized the growth and development of human behaviors and activities, cultures, and states as 'natural' outcomes of the physical environment in which they were found. Non-western peoples were characterized as violent and uncivilized in response to harsh climates, extreme topography, resource availability, dangerous wildlife and other environmental factors, which justified their colonization and devalued their contributions to humanity. Anthropologists and others have distanced themselves from this line of study, although remnants of environmentally deterministic approaches continue to influence analyses of climate change-violence relationships. The influence of environmental determinism emerges in simplistic explanations of cultural, economic, and political changes, missing narratives of human agency and personal choice in descriptions of human-environment interactions, the weighting of environmental factors more heavily than social factors as drivers of human behaviors and choices, a failure to acknowledge 
the complex and differential impacts of environmental change on societies with high inequality, and the separation of humans from their environment [7, 39-41]. These critiques are important considerations in the study of climate change-violence relationships because acts of violence represent individual decisions based on dynamic and complex, ongoing interactions between humans and between humans and their surrounding environment.

Malthusian arguments exemplify the recycling of environmental determinism in contemporary analysis by oversimplifying the relationship linking violent responses to climate change through famine and overpopulation. We see this in explanations that blame overpopulation as the root cause for famines and climate-influenced violence in the Global South and impoverished communities in the Global North. These narratives provide justifications that allow powerful Western military and humanitarian interests to leverage additional power in these regions through interventions [42]. Numerous studies have shown that extreme weather and climate shifts can destabilize food systems and create food shortages through harvest failures, crop blights, and pest outbreaks [24, 43-45]. Growing populations do place pressure on limited food supplies, and food shortages do stress community health and well-being. However, if adequate support systems are in place for sharing the limited, available production and distributing stored reserves, famine risks are reduced. Comprehensive analyses show that poor governance and institutional failure push food shortages into famine [44, 45]. People living under such reduced social conditions compounded by food insecurity may see violence as the best option for gaining direct access to food or control over other resources to leverage their food security when compared to further reductions in well-being from malnutrition and disease. Exploration of political processes and power dynamics in resource access at multiple levels, paying special attention to the identities, alliances, and benefits of involved individuals and groups, helps to tease out additional specifics regarding the social and environmental conditions supporting violence following a climate event or longer term change [46].

\section{Climate Change and Structural Violence}

Structural violence significantly contributes to the social inequalities and reduced resource access that increase risks of physical harm and mortality for certain segments of the population from altered climate patterns. Formal and informal institutional policies and practices that favor one group over another generate patterns of unequal access to basic, necessary resources like healthcare, clean water and sanitation, safe housing, information and education, transportation, and food security [6-8]. These harmful social arrangements may discriminate based on economic status, gender, age, race/ethnicity, caste, disability, or other personal characteristics. While many recognize that climate change can exacerbate inequalities, these pre-existing inequalities often have a greater than expected effect [7, 47]. Structural violence can place people in the path of direct climate harm, such as siting low income housing in areas that flood regularly. It may also act indirectly through neglect by allowing deliberate ignorance, financial 
interests, and political ideologies, rather than sound science and engineering, to dictate government policies regarding adaptive measures protecting people from ongoing and future climate harm.

Structural violence also affects climate change-violence relationship in ways that have not been widely recognized. International policies and markets promoting carbon sequestration and offsets in response to global climate change, like UN-REDD+, industrial tree plantations, biofuel production, and conservation land use policies, promote land grabs that displace populations and drive violent confrontations [48]. Environmental commodity markets, conservation organizations, ecotourism markets, and the state and paramilitaries that enforce these new carbon policies benefit at the expense of the farmers, herders, and others who lose access to the land and water resources necessary for their livelihoods. On the other side of the carbon equation, fossil fuel production shapes climate change-influenced violence through structural violence as well. International financial interests and states displace communities through legal structures to access the wealth of petroleum, coal, and natural gas reserves underground. Community resistance to extraction and pipeline operations has devolved into violent conflict as seen in Nigeria and Sudan; particularly when state militaries and paramilitaries are brought in to enforce land leasing agreements or government policies privileging energy production over human wellbeing [7, 49-52]. In the United States, community members and supporters were seriously injured protesting the construction of the Dakota Access Pipeline at Standing Rock Indian Reservation when a private security firm and the state police used pepper spray, trained guard dogs, rubber bullets, stun grenades, and water cannons in freezing temperatures to deter activists $[53,54]$. Clearly, social, economic, and political inequalities complicate causal explanations for the climate change-violence relationship.

\section{Cooperation and Climate Change}

Research has shown that violence is not always inevitable when resources are scarce and inequalities exist. In Israel's Negev desert, conflict between Muslim Bedouin herders and Jewish settler farmers remained limited, and many cooperated to prevent the loss of livestock during a severe drought from 1957 to 1963. Intervention by the Ministry of Agriculture initially generated conflict, but institutional learning led to new policies that supported cooperation between communities by compensating for crop losses, getting herds access to water and food, and providing alternative income sources for farmers and herders [11]. Research on gender and climate change suggests there may be gendered differences in cooperation. Women are often more willing to seek non-violent and innovative solutions in resource scarce situations to ensure that their families are prepared for climate disasters and recover afterward. And while men may take more risks, they are also more willing to cooperate with people they do not know well under stressful conditions [9]. Increasing women's participation in climate adaptation and mitigation decision-making could lead to reduced violence in response to climate changes. 
Multiple lines of evidence from the southern Levant - Israel, Jordan, Lebanon, and Syria document an absence of warfare from the start of the Neolithic Revolution ( 11,000 BCE) until the start of the Bronze Age (3500-3300 BCE). Climate fluctuations during the Younger Dryas encouraged domestication in this region and set the stage for profound structural social change [55]. As sedentary communities grew, research results suggest a unified identity and culture through parallel development of extensive trade networks, shared technologies, cooperative production and distribution, collective ceremonies, and ritual centers located between major population hubs [17]. Skeletal remains record the existence of interpersonal violence and social inequalities but despite growing preconditions for war, including population growth, climate shifts, and natural resource degradation, cooperative relationships prevented large-scale conflict for approximately 6,700 years [17]. The abrupt appearance of walls and other architectural fortifications around 3300-3050 BCE signals the end of this era, and coincides with development of the southern Levant as a tribal zone, and expansion of Egyptian trade and control into the area.

The disappearance of Norse settlements in Greenland by $1450 \mathrm{CE}$ serves as a reminder that cooperation and flexibility are not always successful. Throughout the North Atlantic, Norse communities developed successful subsistence systems that took advantage of local environmental conditions and community cooperation. Although livestock traveled with the Norse to Greenland, these hunter-farmers communally-hunted seals and developed caribou management practices that allowed their sustainable harvest for almost 500 years $[43,56]$. Declines in trade and agricultural food security coincided with increasing isolation from the northern European mainland. Thule Inuit hunters expanding into southern Greenland around this same time period offered examples of alternative technologies and knowledge for adaptation, but available evidence documents no intercultural exchange, beyond intergroup conflict, or adoption of Inuit technologies by the Norse. As temperatures dropped and storminess and sea ice increased, the Greenlanders intensified their seal hunting [23, 56]. However, the Norse Greenlanders could not anticipate the impacts of a shifting climate on their seal food supply and the colony collapsed despite community cooperation to keep it functioning.

The exploration of non-violent, cooperative responses to climate shocks and longer-term trends is not the focus of this review. However, thinking only about the causal chains leading to physical violence or its absence hinders our ability to comprehensively understand the full range of responses to changing climate conditions [11]. While not always successful, cooperation in small communities and larger confederations demonstrates the power of working together to find non-violent solutions in crisis situations. 


\section{Climate Change and Violence in the Historic and Ethnographic Record}

A growing body of anthropological case studies examines how shifting climate patterns and extreme events act as a trigger and/or additional destabilizing force that disrupts established human-environment interactions and could lead to physical violence. Figure 1 shows a generalized social-environmental system model for thinking about how climate could interrupt established patterns of human-environment interactions at the societal and household level. Here, the environment includes all biophysical elements like biodiversity, biogeochemical cycles, topography, etc., while governance, institutions, \& livelihoods defines a human community's culture of informal institutions and social norms, formal governing institutions and rules, and subsistence activities. Within this interwoven, evolving system are individuals whose production, access, and use of resources is governed by what is available in the environment as much as by their own social conditions as defined by governance, institutions and livelihoods. Resources include elements of the biophysical environment like water, food, pasture, and arable land, as well as infrastructure and the political power gained through access control. Social conditions describe a person's identity within a society and may include any inequalities they experience due to their identity including gender, caste, social position, health, age, religion, race/ethnicity, sexual preference, or economic status.

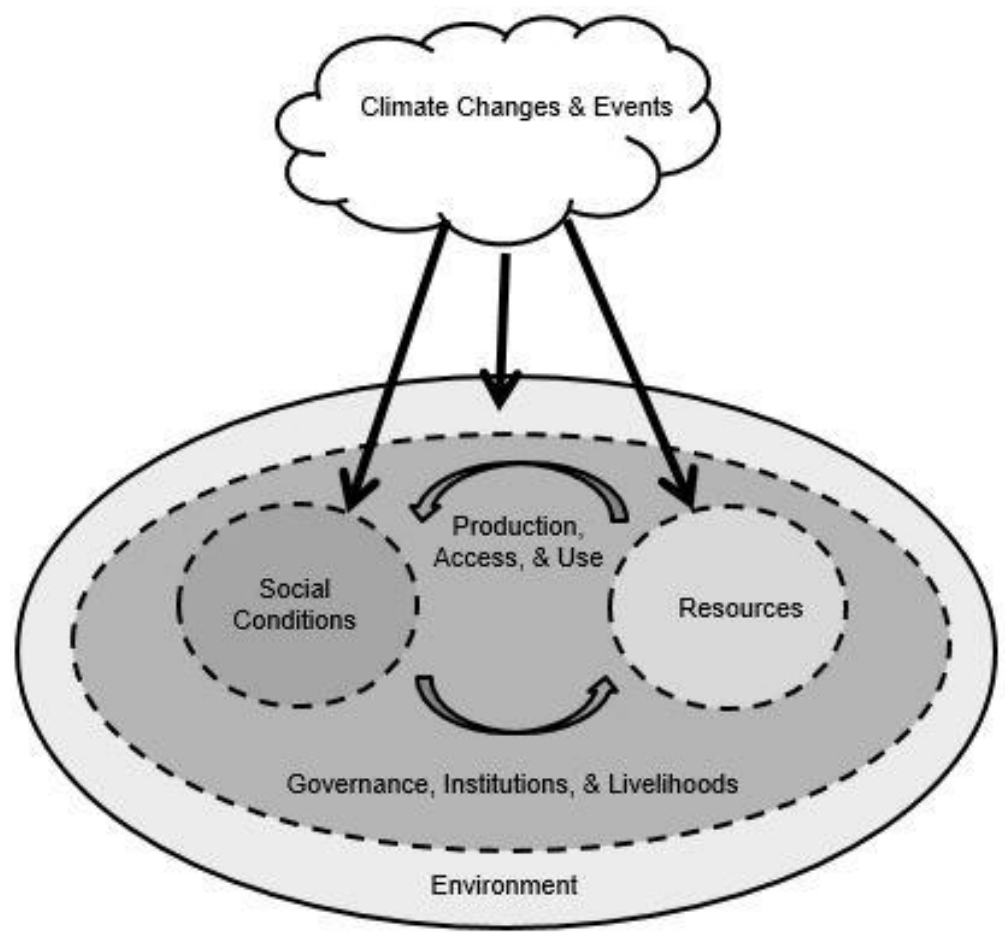

Figure 1. A general model social-environmental system model. Social conditions and preferred resources emerge from the dynamic interactions between the biophysical environment and the governance, institutions, and livelihood activities that are part of local culture. 
Social or environmental changes at any level create instability which ripples throughout the entire system, disrupts established relationships, and increases vulnerability at multiple levels. Shocks from additional climate changes and extreme events at this point in a socialenvironmental system, vulnerable or not, require individuals to make decisions about the best actions they can take to respond to ongoing change and future uncertainty. Individual responses may turn violent where information is limited. Non-existent or weak governance, institutional, and livelihood structures further support choices for violence when they lack the flexibility to accommodate and support human security, or respond to change by reinforcing and expanding inequalities that limit resource access. However, people may choose to cooperate and avoid violence if appropriate cultural mechanisms are in place. Comparative research with historic and contemporary societies suggests that shared social identities promoted through marriage and kinship ties, economic, ecological, and defensive interdependence, non-warring ethics, shared peace symbols and ceremonies, and shared institutions for conflict management promote peaceful resolution of inter- and intra- group disputes [57]. This section explores four case studies, two from the archaeological record and two from the ethnographic record, that examine the relationship between climate change and violence within a broad social-environmental system framework.

\section{Case Studies from the Archaeological Record}

Decades of research regarding Classic Maya civilization have produced a rich body of archaeological evidence and an ongoing fascination as to why this complex society collapsed. Recent discovery of precisely dated cave deposits in Belize offer 2,000 years of subannual rainfall records that, when combined with stone monument inscriptions, broadly track the rise and fall of Classic Maya civilization; however, climate alone is not considered the driver of Maya collapse [58-60]. The climate records show anomalously high rainfall coinciding with population growth and wide scale development of urban political centers throughout Central America 440-660 CE. The high levels of precipitation supported expansion of swidden maize production, and this stability of food and labor, in turn, provided the foundation for the region's growing population, network of small settlements and urban centers, and ruling Maya elites [61, 62]. Between 660-1000 CE, increasingly drier conditions interacted with the Maya socialenvironmental system and triggered large-scale, and sometimes violent, changes. Drier conditions first promoted expansion of rainfed swidden maize fields at the expense of forest and soil erosion to feed the population, which models show likely amplified drying and El Niño droughts by exposing more soils to solar radiation and increasing evapotranspiration rates [61, 63]. Later shifts to raised bed maize production in wetland areas initially worked, but failed when droughts worsened [60]. During this time, the Maya political system encouraged competition between elite rulers through monument construction, grand rituals, and extensive warfare which diverted labor from food production. Failed attempts by elites to expand polities and access additional resources through marriage alliances and warfare paralleled failed rain 
rituals led by divine kings to restore agricultural production [62]. A final series of severe, prolonged droughts 1020-1100 CE acting on a society made vulnerable by political instability, economic losses, environmental degradation, and war encouraged social reorganization and abandonment of large urban centers for smaller, more flexibly adaptive communities [58, 59, 64]. In this transformative relocation, ruling institutions, certain rituals, monumental architecture, and inscribed stone monuments, were significantly altered or abandoned completely $[62,65]$. Central America's extant and vibrant Maya community suggests extensive cooperation among refugees to maintain a cultural identity and rebuild in this period of social transformation.

New research shows a complicated interaction between climate, maize agriculture, population density, and violence among prehispanic pre-Pueblo peoples in the North American Southwest from 200-1300 CE. Proxy climate data indicates a history of rainfall variability punctuated by prolonged droughts, including the Great Drought of 1276-1299 CE which preceded the final abandonment of population dense settlements in the central Mesa Verde and northern Rio Grande areas [66-68]. Reconstruction of populations and agricultural potential in six distinct environmental areas of Mesa Verde show that increases in maize production and use of land amenable to rain-fed maize agriculture strongly correlated to population growth of pre-Pueblo communities [67]. Populations continued to grow even after maximizing the land under maize production, which advanced environmental degradation through deforestation and overhunting of deer. During cooler dry periods, agricultural conditions in parts of Mesa Verde remained stable enough to continue maize production, albeit at a reduced level, which drew people in from more marginal settlements [66-68]. Denser populations during rough periods strained available resources and evidence suggests that, at the societal level, social and political inequalities affected household access to arable land and thus production. Human remains at some of the denser settlements show signs of violent trauma including warfare, massacres, and cannibalism, and in the central Mesa Verde violence tends to be greater during periods of high variance in maize production and low potential production per capita [21,67]. Violent events preceded outmigration and the final abandonment of dense settlements as residents left, likely seeking greater security and a more stable food supply. Research has also shown that violence peaked around mid-1100 CE, and then declined despite continued population growth and ongoing rainfall variability [21]. Archaeological and ethnographic work with descendent populations suggests a period of adaptive learning during the Pueblo transition where refugees and their descendants drew on past experiences to establish more egalitarian and less violent norms, to develop inter-Pueblo sodalities linking communities in positive relationships, and to restructure ritual practices to make them more community-centered $[10,21]$. These actions reduced violent responses to future change by building a more cooperative, flexible, and resilient society. 


\section{Case Studies from the Ethnographic Record}

Darfur's genocide has been described as an ethnic conflict between African farmers and Arab pastoralists and heralded as the first modern climate change war [69-71]. Recent ethnographic research delves into the complex set of interacting factors culminating in the 2003 rebellion of armed groups $[69,71]$. Archived documents record long-standing tribal group conflicts from 1932-2000 over grazing and water rights, land, and administrative politics; however, social and environmental conditions deteriorated in the period between Sudan's independence and the Darfur genocide [69]. After 1956, the newly independent Sudanese government pursued economic and land use policies that fostered resource conflict between African landholding farmers and cattle herders and Arab nomadic camel herders at the household level [71]. Sudan suffered extensive deforestation for consumption, export, and agricultural and pastoral expansion as the nation's population grew. When the droughts hit in the 1980s, influenced by both deforestation and global climate shifts, the underlying social, political, and economic inequalities, most visible in the land-class divide, exploded violently. The severe droughts in northern Darfur forced nomadic pastoralists out of the region in search of pasture and water for their herds and into the territories of other tribes. With the widespread availability of small arms and loss of traditional conflict resolution institutions, confrontations between settled farmers and nomadic pastoralists resulted in extensive casualties. The various warring parties used race and ethnicity to mobilize people to fight over dwindling access to water, pasture, and land. The resulting genocide left more than two million displaced and tens of thousands dead [71].

In East Africa, researchers have noticed higher levels of conflict and ethnic strife in remote locations with scarce water and arable land. Analysis of 5,187 small scale conflict events from 1997 to 2009 in Kenya, Uganda, and Ethiopia found that extremes of rainfall variability influenced different types of violence [72]. During wetter periods, individuals and communities sought to add to their wealth and recruit people to fight on their side. Drier periods favored militarized, rebel raids as people competed for access to scarce water and pasture. However, effective institutional arrangements can moderate and reduce violent conflict during periods of shifting climate. Anthropologists working in Marasbit, Kenya found a similar pattern of conflict and killing during livestock raids in the relatively abundant wet season [73]. However, during the dry season, the pastoralists used established social institutions to reconcile differences, cooperate, and reduce violence over diminishing resources. These local institutions guaranteed access to water in regions where national government structures were weak or absent. Additional work with pastoralists in northern Kenya suggests that empowering women to reduce gender inequality, and providing greater access to education and livelihood diversification opportunities, could also reduce household climate vulnerability in arid and semi-arid regions which could moderate violent events as well [74]. 


\section{Human Security, Future Violence, and Climate Uncertainty}

Anthropology's holistic approach to the climate change-violence relationship suggests that violence is not inevitable. Ongoing studies have identified key social and environmental conditions that influence human agency in choosing violent responses to climate variability, long-term trends, and extreme events. These conditions, which vary spatially and temporally, include resource uncertainty, inflexible, weak, or non-existing governance, institutional structures that support inequality, prior environmental degradation, and profound structural societal changes on the level of sedentization, colonization, and globalization. Furthermore, the impacts of these conditions are felt and acted upon differently depending upon an individual's social position and identity. While there may never be a single theory explaining the connection between climate change and violence, anthropological frameworks and methods offer a springboard for disentangling the complexity of interacting social and environmental conditions involved.

Moving forward, anthropologists should continue their rigorous analysis of historic and contemporary human-environment interactions, as this work strengthens our understandings of the social and environmental conditions preceding violent events and societal collapse. Bounding case studies spatially and temporally to determine an appropriate level of analysis is essential. The impacts of a given climate event or trend vary; a rapid onset event like a flood will affect a community very differently than the early arrival of rains or an extremely wet year. People living in rural areas and small communities will respond differently than urban dwellers because of resource availability, social relationships, and potential conflict sites. Investigation of violence characteristics in response to different types of climate changes, as shown in the East Africa research, is also important [72, 73]. In contemporary studies, long distance connections through global markets and international governance structures should also be considered [8, 47]. Framing climate change-violence research as a spectrum of behaviors from conflict to cooperation would also help pinpoint specifics about conditions leading to cooperation, or at least non-violent situations, as well as violence [8-11, 57]. It is also important to explore whether the conditions leading to violence could have been avoided, the existence of potential tipping points, and the contributions of other less significant, but still important social and environmental conditions.

In focusing this review on physical violence, other types of violence in response to climate change have been left out of the discussion or mentioned only briefly. Ethnographic work with contemporary populations experiencing climate change recognizes structural violence, neglect, and psychological and sexual violence in addition to physical violence. These forms of violence may not kill a person directly, but negatively affect individual security and lifelong well-being. Such small scale events are frequently more difficult to identify in evidence or get people to 
discuss; however, this sort of daily violence has a deep and significant impact on societal vulnerability and resilience to ongoing and future climate change as a whole.

\section{CONCLUSIONS}

An anthropological perspective on the climate change-violence relationship places a strong emphasis on the choices individuals make within the constraints of their personal experiences and knowledge, as well as their surrounding culture and environment. Globally, we see growing social and economic inequality due in part to globalization, but also a legacy of colonialism, imperialism, and other historic restructuring of humanity. This inequality, in many places, is supported by poor governance and reinforced by ideologies that divide people based on their gender, race/ethnicity, religion, economic, and national lines. Pushing planetary limits, via global climate change, biogeochemical cycles, and biological extinction, proceeds simultaneously at a rapid pace due to human activity, population growth, and globalization forces. The social and environmental conditions are ripe for violence, yet we must remember that choices exist. Global climate change could serve as a grand opportunity to reduce inequality, structural violence, and environmental degradation to make the world a more just, equitable, and secure place for all to live.

\section{REFERENCES}

1. Adger WN, Pulhin JM, Barnett J, Dabelko GD, Hovelsrud GK, Levy M, Spring UO, Vogel CH. Human security. In: Field CB, Barros VR, Dokken DJ, Mach KJ, Mastrandrea MD, Bilir TE, Chatterjee M, Ebi KL, Estrada YO, Genova RC, Girma B, Kissel ES, Levy AN, MacCracken S, Mastrandrea PR, White LL (eds.) Climate Change 2014: Impacts, Adaptation, and Vulnerability. Part A: Global and Sectoral Aspects. Contribution of Working Group II to the Fifth Assessment Report of the Intergovernmental Panel on Climate Change. Cambridge, United Kingdom and New York: Cambridge University Press; 2014. p. 755-791.

2. Department of Defense. National security implications of climate-related risks and a changing climate. Congressional Report 150724. 23 July 2015. Available from:

http://archive.defense.gov/pubs/150724-congressional-report-on-national-implications-ofclimate-change.pdf?source=govdelivery [Accessed: 3 April 2017].

3. Hsiang SM, Burke M, Miguel E. Quantifying the influence of climate on human conflict. Science. 2013;341(6151):1235367. DOI: 10.1126/science. 1235367

4. Zhang DD, Lee HF, Wang C, Li B, Pei Q, Zhang J, An Y. The causality analysis of climate change and large-scale human crisis. Proc Natl Acad Sci. 2011;108(42):17296-301. DOI: 10.1073/pnas. 1104268108 
5. Zhang DD, Brecke P, Lee HF, He YQ, Zhang J. Global climate change, war, and population decline in recent human history. Proc Natl Acad Sci. 2007;104(49):19214-9. DOI: 10.1073/pnas.0703073104

6. Farmer P. An anthropology of structural violence. Curr Anthropol. 2004;45(3):305-325. DOI: $10.1086 / 382250$

7. *Bonds E. Upending climate violence research: fossil fuel corporations and the structural violence of climate change. Hum Ecol Rev. 2016;22(2):3-23. Summarizes critiques of research focused on potential violence by poor communities in response to climate change and proposes inclusion of structural violence promulgated by economically powerful.

8. **Fiske SJ, Crate SA., Crumley CL, Galvin K, Lazrus H, Lucero L, Oliver-Smith A, Orlove B, Strauss S, Wilk R. 2014. Changing the Atmosphere: Anthropology and Climate Change. Final report of the AAA Global Climate Change Task Force. December 2014. Arlington, VA: American Anthropological Association; December 2014. Available from: http://s3.amazonaws.com/rdcmsaaa/files/production/public/FileDownloads/pdfs/cmtes/commissions/upload/GCCTFChanging-the-Atmosphere.pdf [Accessed: 3 April 2017]. Excellent overview of anthropological approaches to the study of climate change, from culturally-influenced contributions to climate change to the current and projected impacts on humanity. Climate's impacts on historic and prehistoric humans and hominins are also examined.

9. Dankelman I. Climate change, human security and gender. In: Dankelman I (ed.) Gender and Climate Change: An Introduction. Washington, DC: Earthscan; 2010. p. 55-71.

10. Ortman SG. Discourse and Human Securities in Tewa Origins. Archeological Papers of the American Anthropological Association. 2016;27(1):74-94. DOI: 10.1111/apaa.12075

11. Tubi A, Feitelson E. Drought and cooperation in a conflict prone area: Bedouin herders and Jewish farmers in Israel's northern Negev, 1957-1963. Polit Geogr. 2016;51:30-42. DOI: 10.1016/j.polgeo.2015.11.009

12. American Anthropological Association. AAA statement on humanity and climate change. 29 January 2015, Available from: http://practicinganthropology.org/docs/01-2915_AAA_CCS.pdf [Accessed: 2 May 2017].

13. Liebow E, Waterston A, Barker A, Fiske SJ. A just and sustainable climate for all. 2 June 2017. Available from:

http://www.americananthro.org/ParticipateAndAdvocate/AdvocacyDetail.aspx?ItemNumber $=21771$ [Accessed: 2 May 2017].

14. Malešević S. How old is human brutality? On the structural origins of violence. Common Knowledge. 2016;22(1):81-104. DOI: 10.1215/0961754X-3322894

15. Martin DL, Harrod RP, Pérez VR. Introduction: bioarchaeology and the study of violence. In: Martin DL, Harrod RP, Pérez VR (eds.) The Bioarchaeology of Violence. Gainesville, FL: University Press of Florida; 2012. p. 1-12.

16. Redfern RC. Injury And Trauma In Bioarchaeology: Interpreting Violence In Past Lives. Cambridge: Cambridge University Press; 2017. 
17. *Ferguson RB. The prehistory of war and peace in Europe and the Near East. In Fry, DP (ed.) War, Peace, And Human Nature: The Convergence Of Evolutionary And Cultural Views. Oxford: Oxford University Press; 2013:191-240. Exhaustive and objective overview of available evidence for warfare and interpersonal violence in European and Middle East prehistory during periods of climate change including the Younger Dryas. Offers a solid argument for behavioral plasticity, grounded in evidence, in that humans are capable of both altruistic cooperation and lethal violence depending on the circumstances.

18. Janzen JM. The anthropology of violence: Context, consequences, conflict resolution, healing, and peace-building in Central and Southern Africa. Journal Public Health Policy. 2016;37(Suppl 1):122-32. DOI: 10.1057/s41271-016-008-1

19. Morehart CT. Archaeologies of the Past and in the Present in 2014: Materialities of Human History. Am Anthropol. 2015;117(2):329-44. DOI: 10.1111/aman.12249

20. Harrod RP, Liénard P, Martin DP. Deciphering violence in past societies: ethnography and the interpretation of archaeological populations. In: Martin DL, Harrod RP, Pérez VR (eds.) The Bioarchaeology of Violence. Gainesville, FL: University Press of Florida; 2012. p. 6380.

21. Kohler TA, Ortman SG, Grundtisch KE, Fitzpatrick CM, Cole SM. The better angels of their nature: Declining violence through time among prehispanic farmers of the Pueblo Southwest. Am Antiq. 2014;79(3):444-64. DOI: 10.7183/0002-7316.79.3.444

22. Rodning C. Place, landscape, and environment: Anthropological archaeology in 2009. Am Anthropol. 2010;112(2):180-90. DOI: 10.1111/j.1548-1433.2010.01217.x

23. *Dugmore AJ, McGovern TH, Vésteinsson O, Arneborg J, Streeter R, Keller C. Cultural adaptation, compounding vulnerabilities and conjunctures in Norse Greenland. Proc Natl Acad Sci. 2012;109(10):3658-63. DOI: 10.1073/pnas.1115292109 This study updates previous work and discusses how the Norse Greenlanders created a successful and flexible subsistence system in response to the greater North Atlantic social-environmental system. However, their cooperative climate adaptation was not enough to overcome unforeseen biophysical interactions.

24. McMichael AJ. Insights from past millennia into climatic impacts on human health and survival. Proc Natl Acad Sci. 2012;109(13):4730-7. DOI: 10.1073/pnas.1120177109

25. Fry DP. War, peace, and human nature: the challenge of achieving scientific objectivity. In: Fry, DP (ed.) War, Peace, And Human Nature: The Convergence Of Evolutionary And Cultural Views. Oxford: Oxford University Press; 2013:1-22.

26. Selby J. Positivist climate conflict research: a critique. Geopolitics. 2014;19(4):829-56. DOI: 10.1080/14650045.2014.964865

27. Scheffran J, Brzoska M, Kominek J, Link P, Schilling J. Climate change and violent conflict. Science. 2012;336(6083):869-71. DOI: 10.1126/science.1221339

28. Otterbein KF. A history of research on warfare in anthropology. Am Anthropol. 1999;101(4):794-805. DOI: 10.1525/aa.1999.101.4.794 
29. Allen MW, Bettinger RL, Codding BF, Jones TL, Schwitalla AW. Resource scarcity drives lethal aggression among prehistoric hunter-gatherers in central California. Proc Natl Acad Sci. 2016:201607996. DOI: 10.1073/pnas.1607996113

30. Fry DP, Söderberg P. Lethal aggression in mobile forager bands and implications for the origins of war. Science. 2013;341(6143):270-3. DOI: 10.1126/science.1235675

31. Lahr MM, Rivera F, Power RK, Mounier A, Copsey B, Crivellaro F, Edung JE, Fernandez JM, Kiarie C, Lawrence J, Leakey A. Inter-group violence among early Holocene huntergatherers of West Turkana, Kenya. Nature. 2016;529(7586):394-8. DOI: 10.1038/nature16477

32. Marean $\mathrm{CW}$. The transition to foraging for dense and predictable resources and its impact on the evolution of modern humans. Phil. Trans. R. Soc. B. 2016;371(1698):20150239. DOI: 10.1098/rstb.2015.0239

33. Wendorf F. Site 117: a Nubian final paleolithic graveyard near Jebel Sahaba, Sudan. The prehistory of Nubia. 1968; 2:954-95.

34. Bowles S. Did warfare among ancestral hunter-gatherers affect the evolution of human social behaviors?. Science. 2009;324(5932):1293-8. DOI: 10.1126/science.1168112

35. Ferguson RB. Ten points on war. In: A. Waterston (ed.) An Anthropology of War: Views From The Frontline. New York: Berghan Books; 2009. p. 32-49.

36. Finnström, S, Nordstrom C. War: anthropological aspects, historical development of. In: Wright JD (ed.) International Encyclopedia of the Social \& Behavioral Sciences, 2nd edition, Vol 25. Oxford: Elsevier; 2015. p. 377-381.

37. Waterston A. Introduction: on war and accountability. In: A. Waterston (ed.) An Anthropology of War: Views From The Frontline. New York: Berghan Books; 2009. p. 1231.

38. Sluyter A. Neo-Environmental Determinism, Intellectual Damage Control, and Nature/Society Science. Antipode. 2003;35(4):813-7. DOI: 10.1046/j.14678330.2003.00354.x

39. Contreras D. Correlation is not enough - building better arguments in archaeology to explain human-environment interactions. In: Contreras D (ed.) The Archaeology Of HumanEnvironment Interactions: Strategies For Investigating Anthropogenic Landscapes, Dynamic Environments, And Climate Change In The Human Past. New York: Routledge; 2016. p. 322.

40. Ingold T. Prospect. In: Ingold T, Palsson G (eds) Biosocial Becomings: Integrating Social And Biological Anthropology. Cambridge: Cambridge University Press; 2013. p. 1-21.

41. Ingold T. Perceptions of the Environment: Essays on Livehood, Dwelling and Skill. New York/London: Routledge; 2000.

42. Hartmann B. Converging on disaster: climate security and the Malthusian Anticipatory Regime for Africa. Geopolitics. 2014;19(4):757-83. DOI: 10.1080/14650045.2013.847433

43. Nelson MC, Ingram SE, Dugmore AJ, Streeter R, Peeples MA, McGovern TH, Hegmon M, Arneborg J, Kintigh KW, Brewington S, Spielmann KA. Climate challenges, vulnerabilities, 
and food security. Proc Natl Acad Sci. 2016;113(2):298-303. DOI:

10.1073/pnas.1506494113

44. Slavin P. Climate and famines: a historical reassessment. Wiley Interdiscip Rev Clim Change. 2016;7(3):433-47. DOI: 10.1002/wcc.395

45. Fraser ED. Travelling in antique lands: using past famines to develop an adaptability/resilience framework to identify food systems vulnerable to climate change. Clim Change. 2007;83(4):495-514. DOI: 10.1007/s10584-007-9240-9

46. Schlee, G. 2011. An alternative perspective on contested resources as an explanation for conflict. In: Behrends A, Reyna S, Schlee G (eds.) Crude Domination: An Anthropology of Oil. New York: Berghahn Books; 2011. p. 298-302.

47. Hall E, Sanders T. Accountability and the academy: producing knowledge about the human dimensions of climate change. J R Anthropol Inst 2015;21:438-461. DOI: 10.1111/14679655.12162

48. Dunlap A, Fairhead J. The militarisation and marketisation of nature: An alternative lens to 'climate-conflict'. Geopolitics. 2014;19(4):937-61. DOI: 10.1080/14650045.2014.964864

49. Rogers D. Oil and anthropology. Annu Rev Anthropol. 2015;44:365-80. DOI: 10.1146/annurev-anthro-102214-014136

50. Reyna S, Behrends A. The crazy curse and crude domination: Toward an anthropology of oil. Focaal. 2008;2008(52):3-17. DOI:10.3167/fcl.2008.520101

51. Akpan W. Corporate citizenship in the Nigerian petroleum industry: a beneficiary perspective. Dev South Afr. 2008;25(5):497-511. DOI: 10.1080/03768350802447602

52. Akpan W. Putting oil first? Some ethnographic aspects of petroleum-related land use controversies in Nigeria. Afr Sociol Rev. 2005;9(2):134-52.

53. Wong JC. Dakota Access Pipeline: 300 Protesters Injured After Police Use Water Cannons. The Guardian, 21 November 2016. Available from: https://www.theguardian.com/usnews/2016/nov/21/dakota-access-pipeline-water-cannon-police-standing-rock-protest [Accessed: 15 May 2017].

54. Stelloh T, Roecker M, Sottile CA, Medina DA. Dakota Pipeline: Protesters Soaked With Water In Freezing Temperatures. NBC News, 21 November 2016. Available from: http://www.nbcnews.com/storyline/dakota-pipeline-protests/dakota-pipeline-protestersauthorities-clash-temperatures-drop-n686581 [Accessed: 15 May 2017].

55. Bar-Yosuf O. Climatic fluctuations and early farming in West and East Asia. Curr Anthropol. 2011; 52(S4):S175-193. DOI: 10.1086/659784

56. Dugmore AJ, Keller C, McGovern TH, Casely AF, Smiarowski K. Norse Greenland settlement and limits to adaptation. In: Adger WN, Lorenzoni I, O’Brien KL (eds.) Adapting to Climate Change: Thresholds, Values, Governance. Cambridge: Cambridge University Press; 2009. p. 96-113.

57. Fry DP. Life without war. Science. 2012; 336(6083):879-884. DOI: 10.1126/science. 1217987 
58. Kennett DJ, Breitenbach SF, Aquino VV, Asmerom Y, Awe J, Baldini JU, Bartlein P, Culleton BJ, Ebert C, Jazwa C, Macri MJ. Development and disintegration of Maya political systems in response to climate change. Science. 2012;338(6108):788-91. DOI:

10.1126/science. 1226299

59. Douglas P, Demarest A, Brenner M, Canuto M. Impacts of climate change on the collapse of the lowland Maya civilization. Annu Rev Earth Planet Sci. 2016 44:613-645. DOI: 10.1146/annurev-earth-060115-012512

60. Douglas PM, Pagani M, Canuto MA, Brenner M, Hodell DA, Eglinton TI, Curtis JH. Drought, agricultural adaptation, and sociopolitical collapse in the Maya Lowlands. Proc Natl Acad Sci. 2015;112(18):5607-12. DOI: 10.1073/pnas.1419133112

61. Kennett DJ, Beach TP. Archeological and environmental lessons for the Anthropocene from the Classic Maya collapse. Anthropocene. 2013;4:88-100. DOI:

10.1016/j.ancene.2013.12.002

62. Lucero LJ. Water And Ritual: The Rise And Fall Of Classic Maya Rulers. University of Texas Press; 2006.

63. Cook BI, Anchukaitis KJ, Kaplan JO, Puma MJ, Kelley M, Gueyffier D. Pre-Columbian deforestation as an amplifier of drought in Mesoamerica. Geophys Res Lett. 2012;39(16). DOI: 10.1029/2012GL052565

64. Turner BL, Sabloff JA. Classic Period collapse of the Central Maya Lowlands: Insights about human-environment relationships for sustainability. Proc Natl Acad Sci. 2012;109(35):13908-14. DOI: 10.1073/pnas.1210106109

65. Nelson BA, Chase AS, Hegmon M. Transformative relocation in the US Southwest and Mesoamerica. Archaeological Papers of the American Anthropological Association. 2014; 24(1):171-182. DOI: 10.1111/apaa.12036

66. Matson RG, Lipe WD, Curewitz D. Dynamics of the Thirteenth-century Depopulation of the Northern San Juan: The View from Cedar Mesa. Kiva. 2015;80(3-4):324-49. DOI: 10.1080/00231940.2016.1147162

67. Schwindt DM, Bocinsky RK, Ortman SG, Glowacki DM, Varien MD, Kohler TA. The social consequences of climate change in the central Mesa Verde region. Am Antiq. 2016;81(1):7496. DOI: 10.7183/002-7316.81.1.74

68. Bellorado BA, Anderson KC. Early Pueblo responses to climate variability: Farming traditions, land tenure, and social power in the Eastern Mesa Verde region. Kiva. 2013;78(4):377-416. DOI: 10.1179/0023194013Z.0000000007

69. *Abouyoub Y. Climate: The Forgotten Culprit. The Ecological Dimension of the Darfur Conflict. Race, Gender \& Class. 2012:150-76. An interesting ethnographic analysis of the various environmental and social factors contributing to the Darfur genocide.

70. UNEP Sudan: post-conflict environmental assessment. Available from: http://postconflict.unep.ch/publications/UNEP_Sudan.pdf [Accessed on: 23 April 2017]. 
71. Kuznar LA, Sedlmeyer R. Collective violence in Darfur: an agent-based model of pastoral nomad/sedentary peasant interaction. Mathematical Anthropology and Cultural Theory. 2005;1(4):1-22.

72. Raleigh C, Kniveton D. Come rain or shine: An analysis of conflict and climate variability in East Africa. J Peace Res. 2012;49(1):51-64. DOI: 10.1177/0022343311427754

73. *Adano WR, Dietz T, Witsenburg K, Zaal F. Climate change, violent conflict and local institutions in Kenya's drylands. J Peace Res. 2012 ;49(1):65-80. DOI:

$10.1177 / 0022343311427344$ A fascinating analysis of the relationship between climate and interethnic violence that also brings in discussion of the important role of local institutions in reducing violence.

74. Opiyo FE, Wasonga OV, Nyangito MM. Measuring household vulnerability to climateinduced stresses in pastoral rangelands of Kenya: Implications for resilience programming. Pastoralism. 2014;4(1):10. DOI: 10.1186/s13570-014-0010-9 